\title{
Frequency of Anxiety, Depression and Stress among Pharmacy Undergraduates of Annual and Semester System: A Cohort-Based Comparison
}

\author{
Mehmood Azam ${ }^{1}$, Rabia Ishaq ${ }^{1}$, Qaiser Iqbal ${ }^{1}$, Syed Umer Jan ${ }^{1}$, Mohammad Alam Mengal' ${ }^{2}$ Fahad Saleem ${ }^{1, *}$ \\ ${ }^{1}$ Faculty of Pharmacy and Health Sciences, University of Balochistan, Quetta, PAKISTAN. \\ ${ }^{2}$ Centre for Advanced Studies in Vaccinology and Biotechnology, University of Balochistan, Quetta, PAKISTAN.
}

\begin{abstract}
Received: 08 August 2020;
Accepted: 27 September 2020

*Correspondence to:

Dr. Fahad Saleem,

Quetta, PAKISTAN.

Email:fahaduob@gmail.com original work is properly cited.
\end{abstract}

Associate Professor, Faculty of Pharmacy and Health Sciences, University of Balochistan,

Copyright: (C) the author(s),publisher and licensee Indian Academy of Pharmacists. This is an open-access article distributed under the terms of the Creative Commons Attribution Non-Commercial License, which permits unrestricted non-commercial use, distribution, and reproduction in any medium, provided the

\begin{abstract}
Objectives: The current study was aimed to evaluate the anxiety, depression and stress (AD\&S) among two different academic performance systems (i.e. semester and annual system). Methods: A questionnairebased, cross-sectional survey technique was adopted. The Depression, Anxiety and Stress Scale (DASS) was used to assess the AD\&S among pharmacy undergraduates enrolled at Faculty of Pharmacy and Health Sciences, University of Balochistan Quetta. SPSS v 20.0 was used for data coding and analysis whereas both descriptive and inferential statistics were used for data elaboration. Results: Two hundred and eighty-nine pharmacy undergraduates participated in the study with a distribution of $43.3 \%$ belonging to the annual academic system and $56.7 \%$ from the semester system. Students Majority were of 20 years old $(59,20.4 \%)$, including both male $(194,67.1 \%)$ and female $(95,32.9 \%)$. The mean AD\&S scores of the entire cohort were $14.15 \pm 9.3,13.61 \pm 7.9$ and $18.18 \pm 8.2$ respectively representing moderate $A D \& S$ among pharmacy undergraduates. Statistically significant difference $(p<0.05)$ was reported among students of annual and semester system for all three variables of study whereby the students of semester system were more in AD\&S as compared to the annual system. Conclusion: Based on the findings of current study it is suggested that measure should be taken to reduce the AD\&S among students for better academic performance. This is achievable by engaging students by inquiring their queries and problems faced during the semester-related activities. By doing so, a stress-free environment is predicted hence bringing academic prosperity among students leading to the development of a more qualified and satisfied future pharmacist. Key words: Anxiety, Depression, Stress, Pharmacy, Undergraduates.
\end{abstract}

\section{INTRODUCTION}

Stress is connected to human life and its effects on mental and physical health is broadly investigated in academic and scientific research. ${ }^{[1]}$ Where stress induced by academic activities generate sense of motivation and competition among students and encourages learning, ${ }^{[2]}$ it sometimes develops anxiety and depression that results helplessness and poor academic performance..$^{[3]}$ The literature reports that because of the very immense academic pressure students are indulged in academic misconduct and substance abuse. ${ }^{[4]}$ Few students quit their academic programs while some are also reported to have attempted suicides. ${ }^{[5]}$ In literature the term 'academic stress' has been widely used to assess incidence and impact of stress related to studies on students and their performance which may be affected negatively. ${ }^{[6]}$ Another term 'examination related stress' has also been reported in literature but it is difficult to determine how much the both terms overlie. Examination is the essential part of academic activities and stress induced by examination is considered as subtype of academic stress therefore, examination stress is more focused to evaluate the academic stress. ${ }^{[6-8]}$ Within this context, medical and pharmacy students generally must go through a comprehensive curriculum and competitive environment throughout their studies. ${ }^{[9]}$ Hence, students continually experience mental distress due to fear and dissatisfaction related to academic failure. A high prevalence of stress (12.9\%) and rate of suicide attempt $(2.7 \%)$ was reported in medical students of Sweden. ${ }^{[10]}$ Another study explored the prevalence of academic stress in Thai medical students and found a surprising figure of $61.4 \% \cdot{ }^{[11]}$ As far as the Pakistani medical students are concerned, they have shown $20.8 \%$ prevalence of stress which was strongly coupled with reduced academic performance in Lahore, Pakistan. ${ }^{[12]}$ Numerous other studies have also reported elevated level of stress among medical students ${ }^{[13]}$ whereas few studies compared the level of stress among undergraduates (medical and non-medical students) and revealed high level of academic stress in medical students. ${ }^{[10,14]}$ In Pakistan, Higher Education Commission (HEC) of Pakistan is responsible for formulation and standardization of pharmacy curriculum; it is continually improved, revised and implemented throughout Pakistan to sustain consistency and harmonization among all pharmacy institutions of Pakistan. Pharmacy institutes of Pakistan mainly follow module-based curriculum which is further divided into two methods of assessment widely accepted by the pharmacy colleges. Among these one of the systems is based on annual examination in which students' performance is evaluated as either pass or fail and result is interpreted as percentile. While others employ semester system with two semesters per annum and students must appear four times in the examination every year. Result of the students following the semester system is presented by calculating Grade Point Average (GPA). It is very similar to other gradetiered assessment systems. ${ }^{[15]}$ Inline to what is reported, HEC changed its policy and recommended to implement semester system throughout the Pakistan in 2017. Where quite a few pharmacy institutes have adopted semester system, it is in transitory stage and at the same time senior students 
are going through annual system whereas juniors are going through semester system. While considering the evaluation of students in revised system, the need arises to assess the depression and anxiety related to academic stress along with its prevalence against the significance of educational outcomes. According to literature review we could not find any study conducted in Quetta, Pakistan to assess academic stress in students undergoing annual and semester system. Therefore, we designed this cross-sectional study to compare level of academic stress between pharmacy students enrolled in conventional annual system and newly implemented semester system with the aim to identify which system keeps the stress level to minimum while keeping students' performance intact.

\section{METHODOLOGY}

\section{Study design and settings}

The study design was cross-sectional and the research was conducted at the Faculty of Pharmacy and Health Sciences, University of Balochistan Quetta. The University came into being with the promulgation of the University of Balochistan Ordinance 1970. In terms of human resource, the province of Balochistan is passing through a process of rapid socioeconomic development and needs well qualified and competent scientists, professionals, academicians and administrators. The University is cognizant of this need and prepared to provide meaningful higher education to the youth of the province. The University is committed to develop and sustain an environment conducive to excellence in teaching, learning, research and spread of knowledge. ${ }^{[16]}$

\section{Study duration, sampling technique and inclusion criteria}

The study was conducted for 8 months i.e. March to October 2019. Universal sampling was adopted and all students enrolled for the pharmacy program were contacted for data collection. ${ }^{[17]}$ Students enrolled in the morning program and willing to participate in the study were included.

\section{Study tool}

The Depression, Anxiety and Stress Scale (DASS) is a valid and reliable tool used for the assessment of AD\&S. It comprises of 42 self-reported items to be completed over five to ten minutes, each reflecting an emotional symptom. ${ }^{[18]}$ The questionnaire was developed in English language then translated into Urdu by using standard procedure for the convenience of students. The questionnaire was self-completed and included two major parts. The first part included questions about personal characteristics of the respondent. Second part involved questions related to respondent's perception regarding $\mathrm{AD \& S}$.

\section{Data collection}

Written consent was taken from all the participants ensuring their anonymity and confidentiality. All questionnaires were filled on the spot and were cross checked for completion and all errors or discrepancies were resolved. The obtained data was entered and analyze in Statistical Package for the Social Sciences (SPSS) version 21. Bothe descriptive and inferential statistics were used with $p<0.05$ taken as significant.

\section{Ethical approval}

Institutional ethical committee of Faculty of Pharmacy and Health Sciences approved the study. In addition, permission from the Dean, Faculty of
Pharmacy and Health Sciences was also taken prior to the data collection.

\section{RESULTS}

Table 1 presents demographic characteristics of the study respondents. Out of 425 enrolled students, 289 participated with a response rate of $68 \%$. Majority of the respondents were 20 year $(59,20.4 \%)$. The cohort was dominated by males $(194,67.1 \%)$. Sixty-six $(22.8 \%)$ students were from first professional followed by $(53,18.3 \%),(45,15.6 \%),(57,19.7 \%)$ and $(68,23.5 \%)$ from second, third, fourth and fifth professional respectively. Out of these, data were collected from 125 students of annual system (fourth and fifth year) and 164 students of semester system (first, second and third year).

\section{Assessment of anxiety, depression and stress among the pharmacy undergraduates}

The AD\&S were scored as per criteria proposed by the developers. ${ }^{[18]}$ The mean AD\&S scores of the entire cohort were 14.15 $\pm 9.3,13.61 \pm 7.9$ and $18.18 \pm 8.2$ respectively representing moderate AD\&S among pharmacy undergraduates. The scores and the distributions are presented in Table 2-4 respectively.

\section{Comparison of anxiety, depression and stress among annual and semester system (intergroup analysis)}

The intergroup analysis is presented in Table 5. The Man Whitney test was used for comparing annual system with semester system. A statistically significant difference $(p<0.05)$ was reported among all three variables (anxiety, depression and stress). The interpretation of the mean ranks revealed students of the semester system being faced with AD\&S when compared to the students of annual system (high rank being a reflective of faced with more (AD\&S).

\section{DISCUSSION}

Among various disciplines, pharmacy is one of the renowned professions offering individuals a rewarding and meaningful career. However, it is not surprising that pharmacy education is meticulous and challenging venture which is carried out in a competitive professional atmosphere. ${ }^{[19]}$ In such a challenging environment there are several stressors which can affect health

\begin{tabular}{|c|c|c|}
\hline Demographics & Frequency & Percentage \\
\hline $\begin{array}{l}\text { Age of respondents } \\
18 \\
19 \\
20 \\
21 \\
22 \\
23 \\
24 \\
25\end{array}$ & $\begin{array}{l}11 \\
32 \\
59 \\
44 \\
50 \\
46 \\
27 \\
47\end{array}$ & \begin{tabular}{l|}
3.8 \\
11.1 \\
20.4 \\
15.2 \\
17.3 \\
15.9 \\
9.3 \\
16.2 \\
\end{tabular} \\
\hline $\begin{array}{l}\text { Gender } \\
\text { Male } \\
\text { Female }\end{array}$ & $\begin{array}{l}194 \\
95\end{array}$ & $\begin{array}{l}67.1 \\
32.9\end{array}$ \\
\hline $\begin{array}{l}\text { Year of study } \\
\text { First } \\
\text { Second } \\
\text { Third } \\
\text { Forth } \\
\text { Final }\end{array}$ & $\begin{array}{l}66 \\
53 \\
45 \\
57 \\
68\end{array}$ & $\begin{array}{l}22.8 \\
18.3 \\
15.6 \\
19.7 \\
23.5\end{array}$ \\
\hline $\begin{array}{l}\text { Study system } \\
\text { Annual } \\
\text { Semester }\end{array}$ & $\begin{array}{l}125 \\
164\end{array}$ & $\begin{array}{l}43.3 \\
56.7\end{array}$ \\
\hline
\end{tabular}


Azam, et al.: Anxiety, Depression and Stress among Pharmacy Undergraduates

of the students. Change of system of evaluation is one of the stressors, as recently HEC has changed its system of evaluation from annual to semester system. ${ }^{[20]}$ The current study was aimed to identify various psychological disorders among pharmacy students having different mode of evaluation.
The data was collected from 289 pharmacy students having age range from 18-27 years studying in first to final year of pharmacy came from different socio-economic background. Our result agrees to what was reported by Iqbal and colleagues. ${ }^{[21]}$ It is well known because students join pharmacy

\begin{tabular}{|c|c|c|c|c|}
\hline \multirow[t]{2}{*}{ Questions } & \multicolumn{4}{|c|}{ Responses } \\
\hline & $\begin{array}{l}\text { Did not apply } \\
\text { to me at all } \\
\mathrm{N}(\%)\end{array}$ & $\begin{array}{l}\text { Apply to me at all } \\
\text { to some degree } \\
\mathrm{N}(\%)\end{array}$ & $\begin{array}{l}\text { Apply to me to a } \\
\text { considerable degree } \\
\mathrm{N}(\%)\end{array}$ & $\begin{array}{l}\text { Apply to me } \\
\text { very much } \\
\mathrm{N}(\%)\end{array}$ \\
\hline $\begin{array}{l}\text { I couldn't seem to experience any positive } \\
\text { feeling at all }\end{array}$ & $129(44.6)$ & $97(33.6)$ & $47(16.3)$ & $16(5.5)$ \\
\hline I just couldn't seem to get going & $105(36.3)$ & $113(39.1)$ & $45(15.6)$ & $26(9.0)$ \\
\hline I felt that I had nothing to look forward to & $128(44.3)$ & $89(30.8)$ & $38(13.1)$ & $34(11.8)$ \\
\hline I felt sad and depressed & $92(31.8)$ & $103(35.6)$ & $50(17.3)$ & $44(15.2)$ \\
\hline $\begin{array}{l}\text { I felt that I had lost interest in just about } \\
\text { everything }\end{array}$ & $88(30.4)$ & $107(37.0)$ & $63(21.8)$ & $31(10.7)$ \\
\hline I felt I wasn't worth much as a person & $141(48.8)$ & $72(24.9)$ & $35(12.1)$ & $41(14.2)$ \\
\hline I felt that life wasn't worthwhile & $155(53.6)$ & $61(21.1)$ & $46(15.9)$ & $27(9.3)$ \\
\hline $\begin{array}{l}\text { I couldn't seem to get any enjoyment out of } \\
\text { the things I did }\end{array}$ & $103(35.6)$ & $104(36.0)$ & $54(18.7)$ & $28(9.7)$ \\
\hline I felt down hearted and blue & $74(25.6)$ & $108(37.4)$ & $67(23.2)$ & $40(13.8)$ \\
\hline $\begin{array}{l}\text { I was unable to become enthusiastic about } \\
\text { anything }\end{array}$ & $107(37.0)$ & $98(33.9)$ & $58(20.1)$ & $26(9.0)$ \\
\hline I felt I was pretty worthless & $120(41.5)$ & $79(27.3)$ & $53(18.3)$ & $37(12.8)$ \\
\hline $\begin{array}{l}\text { I could see nothing in the future to be } \\
\text { hopeful about }\end{array}$ & $129(44.6)$ & $75(26.0)$ & $39(13.5)$ & $46(15.9)$ \\
\hline I felt that life was meaningless & $150(51.9)$ & $66(22.8)$ & $34(11.8)$ & $39(13.5)$ \\
\hline $\begin{array}{l}\text { I found it difficult to workup the initiative to } \\
\text { do things }\end{array}$ & $84(29.1)$ & $93(32.2)$ & $76(26.3)$ & $35(12.5)$ \\
\hline
\end{tabular}

The mean depression score of the entire cohort was $13.61 \pm 7.9$ indicating moderate level of depression

\begin{tabular}{|c|c|c|c|c|}
\hline \multirow[t]{2}{*}{ QUESTIONS } & \multicolumn{4}{|c|}{ Responses } \\
\hline & $\begin{array}{l}\text { Did not apply to } \\
\text { me at all } \\
\text { N (\%) }\end{array}$ & $\begin{array}{l}\text { Apply to me } \\
\text { at all to some } \\
\text { degree } \\
\mathrm{N}(\%)\end{array}$ & $\begin{array}{l}\text { Apply to me to a } \\
\text { considerable degree } \\
N(\%)\end{array}$ & $\begin{array}{l}\text { Apply to me very } \\
\text { much } \\
\mathrm{N}(\%)\end{array}$ \\
\hline I was aware of dryness of my mouth & $121(41.9)$ & $107(37.0)$ & $46(15.9)$ & $15(5.2)$ \\
\hline I had feeling of shakiness & $145(50.2)$ & $81(28.0)$ & $46(15.9)$ & $17(5.9)$ \\
\hline $\begin{array}{l}\text { I found myself in situations that made me so anxious I was most } \\
\text { relieved when they ended }\end{array}$ & $42(14.5)$ & $80(27.7)$ & $84(29.1)$ & $83(28.7)$ \\
\hline I had a feeling of faintness & $151(52.2)$ & $77(26.6)$ & $38(13.1)$ & $23(8.0)$ \\
\hline $\begin{array}{l}\text { I perspired noticeably (e.g. hands sweaty) in the absence of high } \\
\text { temperatures or physical exertion }\end{array}$ & $145(50.2)$ & $77(26.6)$ & $43(14.9)$ & $24(8.3)$ \\
\hline I felt I was close to panic & $94(32.5)$ & $92(31.8)$ & $61(21.1)$ & $42(14.5)$ \\
\hline I feared that I would be "thrown" by some trivial but unfamiliar task & $119(41.2)$ & $85(29.4)$ & $62(21.5)$ & $23(8.0)$ \\
\hline I felt terrified & 127(43.9) & $88(30.4)$ & $43(14.9)$ & $31(10.7)$ \\
\hline $\begin{array}{l}\text { I was worried about situations in which I might panic and make a } \\
\text { fool of myself }\end{array}$ & $83(28.7)$ & $91(31.5)$ & $75(26.0)$ & $40(13.8)$ \\
\hline I experienced trembling (e.g. in the hands) & 132(45.7) & $92(31.8)$ & $49(17.0)$ & $16(5.5)$ \\
\hline
\end{tabular}

The mean anxiety score of the entire cohort was $14.15 \pm 9.3$ indicating moderate level of depression 


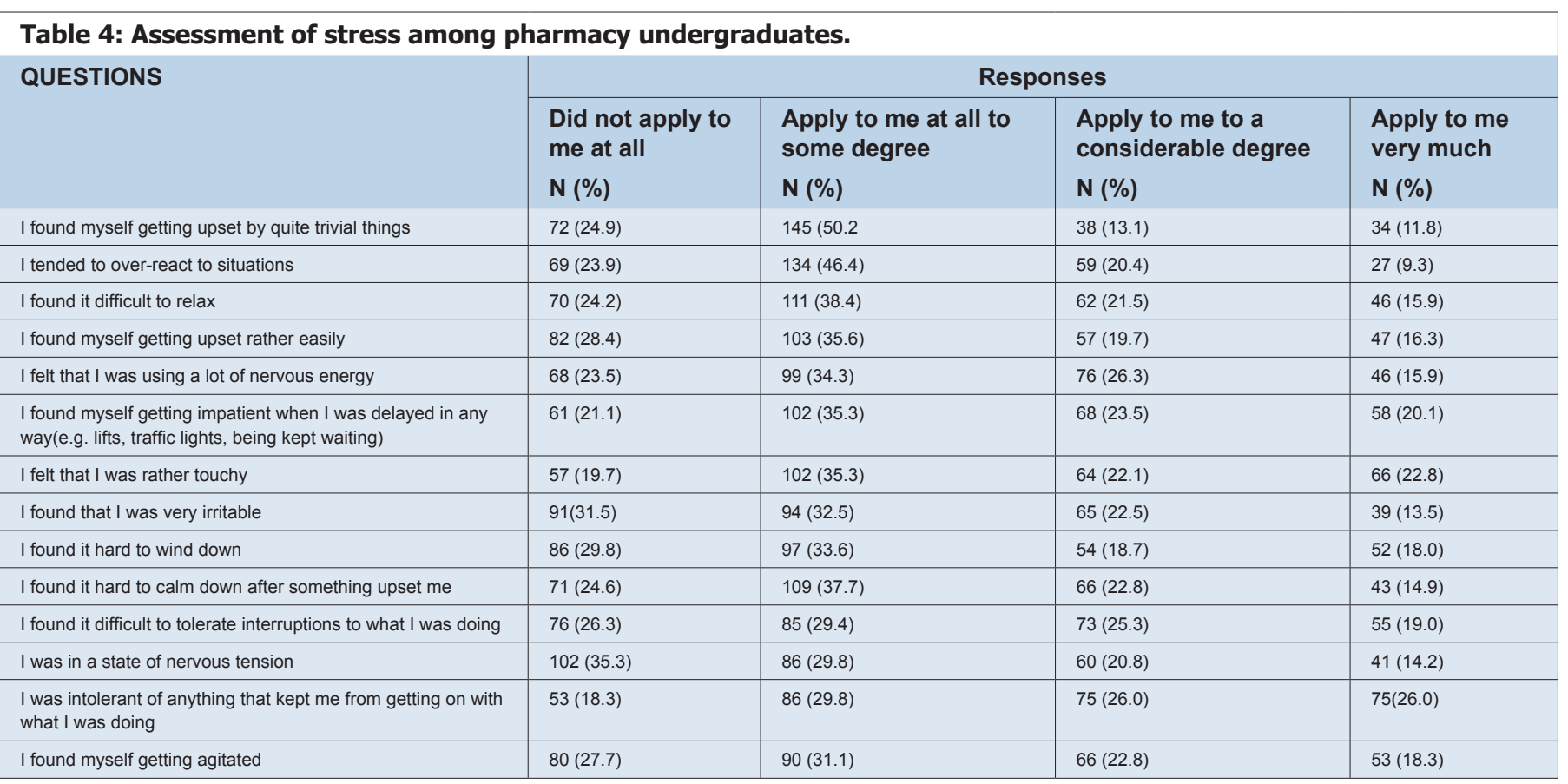

The mean stress score of the entire cohort was $18.18 \pm 8.2$ indicating moderate level of depression

\section{Table 5: Intergroup analysis (students of annual versus the semester system).}

\begin{tabular}{|c|c|c|c|c|}
\hline \multicolumn{2}{|c|}{ Study system } & $\mathbf{N}$ & $P$-value & Mean rank \\
\hline $\begin{array}{l}\text { Total Stress } \\
\text { Semester }\end{array}$ & Annual & $\begin{array}{l}125 \\
164\end{array}$ & 0.034 & $\begin{array}{l}133.10 \\
154.07\end{array}$ \\
\hline $\begin{array}{l}\text { Total Anxiety } \\
\text { Semester }\end{array}$ & Annual & $\begin{array}{l}125 \\
164\end{array}$ & 0.001 & $\begin{array}{l}126.47 \\
159.12\end{array}$ \\
\hline $\begin{array}{l}\text { Total Depression } \\
\text { Semester }\end{array}$ & Annual & $\begin{array}{l}125 \\
164\end{array}$ & $<0.001$ & $\begin{array}{l}123.75 \\
161.20\end{array}$ \\
\hline
\end{tabular}

program immediately after completion of their intermediate in pre-medical, which is the prerequisite of Pharmacy Council of Pakistan. ${ }^{[2]}$ Further, all those students who acquired their degrees in intermediate in last two years can take admission in Pharmacy thus the age proportion remain the same in every pharmacy school. Male participants dominated the cohort in the present study by $67.1 \%$ contradicting to the result of other study by Mayer and colleagues. ${ }^{[23]}$ Possible reason for this contradicting result is that in Balochistan province people don't favor female education therefore, only bright female students who do well in their school and college qualify for pharmacy profession. In addition, co-education is not preferred in the area whereas University of Balochistan is the only institute offering Pharmacy education and it offers co-education, resulting in decreased number of female students.

In our study the students learning in annual and semester system were $43.3 \%$ and $56.7 \%$ respectively. Difference in these values is due to transition stage between annual to semester system, initial three professionals were studying in semester while the last two were in annual thus, the percentage in semester is at higher side. Overall moderate AD\&S was reported by the pharmacy students in our study, the findings are in line to what was also reported in western countries. In United Kingdom, 24\% prevalence of depression was reported among medical students. ${ }^{[4]}$ Students of Michigan Medical School were reported to have $14.3 \%$ prevalence of depression. ${ }^{[25]}$ In Pakistan the reported prevalence rate was $57.6 \%{ }^{[26]}$ and variety of reasons can be ascribed to these fractions of increased prevalence in this region. A correlation was reported in anxiety and depression with frustration in evaluation criteria, overstrained test plans and stress to qualify exams. ${ }^{[27]}$ In Pakistan there is a lot of pressure by the families to choose pharmacy profession which is followed by the pressure of doing well in the academics. Stress among medical pharmacy is seen frequently but it is under reported and under treated. Further the students seldom search for expert opinion, generally due to disgrace regarding mental fitness.

Findings of our study revealed that depression among students of annual system is less (mean rank 123.75) as compared to semester system (mean rank 161.20) representing a larger extent of assessment linked anxiety in students registered in the semester system. Like the results of our study another identical research was conducted in Mayo Medical School which revealed the minimum level of stress assumed by the students evaluated in annual, as compared to the students assessed according to five interval grading system. ${ }^{[28]}$ Another study conducted at University of Virginia reported that by applying annual system of assessment in medical school, students showed greater degree of satisfaction, personal lives and psychological wellbeing. ${ }^{[29]}$ Lastly, a study conducted in medical schools of United States reported that high level of stress and emotional fatigue was seen in students assessed through semester system, as this system increased the possibility of dropping out of school by the student altogether. ${ }^{[30]}$ Annual system of evaluation was believed to distort distinctions among students of diverse educational capabilities and decrease motivation of the students. On the contrary semester system of evaluation was considered to support students in taking regular classes, letting pharmacy schools to offer exigent courses with consistent grading and encourage students to participate on a standardized platform. This system of evaluation is associated in success of studies, development of career and attainment. ${ }^{[31]}$ Whereas, in other studies it was revealed that annual system of evaluation did not diminish motivation and performance of students in medical schools, but annual system found to be coupled with increased degree of contentment with standard of education and performance as compared to semester system. ${ }^{[5,29]}$ Our result was consistent 
to these studies, where students of annual system were completely satisfied regarding academic performance when compared with the semester system.

\section{CONCLUSION}

Our study concluded that students evaluated under annual system have relatively reduced stressful academic life as compared to students with semester system. Therefore, when grading system must be formulated for pharmacy students, the one which puts less stress must be preferred over the other considering students' comfort and academic outcome. Higher Education Commission of Pakistan which is a governing body for designing and implementing curricula and mode of assessment may revise the framework and utilize a homogeneous system of evaluation in pharmacy institutes, which may have positive effects on student's life by reducing stressors, enhancing performance and adopting a better professional career.

\section{Limitations}

Our study was single centered and convenient sampling method was used which does not eliminate the risk of selection bias. A multicenter study involving more pharmacy institutes with larger sample size evaluating academic stress independently will present improved insight of the subject.

\section{CONFLICT OF INTEREST}

The authors declare no conflict of interest. No funding was received for this study.

\section{REFERENCES}

1. Buchwald P. Stress and anxiety: Application to health, work place, community and education. Cambridge Scholars Publishing, London, UK. 2009.

2. Mostofsky DI, Barlow DH. The management of stress and anxiety in medical disorders. Allyn and Bacon, Massachusetts, USA. 2000.

3. Posselt JR, Lipson SK. Competition, anxiety and depression in the college classroom: Variations by student identity and field of study. J Coll Stud Dev. 2016;57(8):973-89.

4. Zaid ZA, Chan SC, Ho JJ. Emotional disorders among medical students in a Malaysian private medical school. Singapore Med J. 2007;48(10):895-9.

5. Spring L, Robillard D, Gehlbach L, Simas TAM. Impact of pass/fail grading on medical students' well $\square$ being and academic outcomes. Med Educ. 2011;45(9):867-77.

6. Akgun S, Ciarrochi L. Learned resourcefulness moderates the relationship between academic stress and academic performance. Educ Psycho. 2003;23(3):287-94.

7. Connor MJ. Pupil stress and standard assessment tasks. Emot Behav Diffic. 2001;6(2):103-11.

8. Ali M, Asim H, Edhi MI, Hashmi MD, Khan MS, Naz F, et al. Does academic assessment system type affect levels of academic stress in medical students? A cross-sectional study from Pakistan. Med Edu Online. 2015;20(1):27706.

9. Dyrbye LN, Thomas MR, Shanafelt TD. Systematic review of depression, anxiety and other indicators of psychological distress among US and Canadian medical students. Acad Med. 2006;81(4):354-73.

10. Dahlin M, Joneborg N, Runeson B. Stress and depression among medical students: A cross $\square$ sectional study. Med Educ. 2005;39(6):594-604.

11. Saipanish R. Stress among medical students in a Thai medical school. Med Teach. 2003;25(5):502-6.

12. Sohail N. Stress and academic performance among medical students. J Coll Physicians Surg Pak. 2013;23(1):67-71.

13. Sherina M, Rampal L, Kaneson M. Psychological stress among undergraduate medical students. Med J Malaysia. 2004;59(2):207-11.

14. Behere SP, Yadav R, Behere PB. A comparative study of stress among students of medicine, engineering and nursing. Indian J Psychol Med. 2011;33(2):145-8.

15. Higher Education of Pakistan. Higher Education of Pakistan. 2013. https://www. pharmacycouncil.org.pk/doc/Pharm\%20D\%20Curriculum\%20Final\%202013. pdf. University of Balochistan. University of Balochistan. 2016. http://www.uob. edu.pk/prospectus/Prospectus-BS-2015.pdf. Pourhoseingholi MA, Vahedi M, Rahimzadeh R. Sample size calculation in medical studies. Gastroenterol Hepatol Bed Bench. 2013;6(1):14-7.

16. Lovibond PF, Lovibond SH. The structure of negative emotional states: Comparison of the Depression Anxiety Stress Scales (DASS) with the Beck Depression and Anxiety Inventories. Behav Res Ther. 1995;33(3):335-43.

17. Shah M, Hasan S, Malik S, Sreeramareddy CT. Perceived stress, sources and severity of stress among medical undergraduates in a Pakistani medical school. BMC Medical Education. 2010;10(1):2.

18. Higher Education Comission of Pakistan. Policy Guidelines for the Implementation of Uniform Semester System in Higher Education Institutions of Pakistan. 2015. https://hec.gov.pk/english/services/universities/Documents/Draft-Policyguidelines.pdf.

19. Iqbal S, Gupta S, Venkatarao E. Stress, anxiety and depression among medical undergraduate students and their socio-demographic correlates. Indian J Med Res. 2015;141(3):354-357.

20. Madiha $M$, Yang CQ. Curriculum and Pharmacy practice experience offered for Pharm-D in Pakistan: Needs and possibilities. Int Curr Pharm J. 2014;3(8):313-7.

21. Mayer FB, Santos IS, Silveira PSP, Lopes MHI, DeSouza AR, Campos EP, Abreu BA, et al. Factors associated to depression and anxiety in medical students: A multicenter study. BMC Medical Education. 2016;16(1):282.

22. Dahlin ME, Runeson B. Burnout and psychiatric morbidity among medical students entering clinical training: A three year prospective questionnaire and interviewbased study. BMC Medical Education. 2007;7(1):6.

23. Schwenk TL, Davis L, Wimsatt LA. Depression, stigma and suicidal ideation in medical students. J Am Med Assoc. 2010;304(11):1181-1190.

24. Rab F, Mamdou R, Nasir S. Rates of depression and anxiety among female medical students in Pakistan. East Mediterr Health J. 2008;14(1):126-33.

25. Rehmani N, Khan QA, Fatima SS. Stress, Anxiety and Depression in students of a private medical school in Karachi, Pakistan. Pak J Med Sci. 2018;34(3):696-701.

26. Rohe DL, Barrier PA, Clark MM, Cook DA, Vickers KS, Decker PA. The benefits of pass-fail grading on stress, mood and group cohesion in medical students. Mayo Clin Proc. 2006;81(11):1443-8

27. Bloodgood RA, Short J, Jacjson JM, Martindale J. A change to pass/fail grading in the first two years at one medical school results in improved psychological well-being. Acad Med. 2009;84(5):655-62.

28. Reed DA, Shanafelt TD, Satele DW, Power DV, Eacker A, Harper W. Relationship of pass/fail grading and curriculum structure with well-being among preclinical medical students: A multi-institutional study. Acad Med. 2011;86(11):1367-73.

29. Cohen-Schotanus J, Muijtjens AM, Reinders JJ, Agsteribbe J, Rossum MJV, Vleuten PM. The predictive validity of grade point average scores in a partial lottery medical school admission system. Med Edu. 2006;40(10):1012-9.

Cite this article as: Azam M, Ishaq R, Iqbal Q, Jan SU, Mengal MA, Saleem F. Frequency of Anxiety, Depression and Stress among Pharmacy Undergraduates of Annual and Semester System: A Cohort-Based Comparison. J Pharm Pract Community Med. 2020;6(3):35-9. 